\title{
Nutritional Relationships and Accumulation Capacity of Broccoli (Brassica Oleracea var. Italica) Grown Under the Stress Caused by Some Heavy Metals Seen in Agricultural Areas
}

Sevinç ADILOĞLU ( $\nabla$ sadiloglu@hotmail.com )

Tekirdag Namik Kemal University: Tekirdag Namik Kemal Universitesi https://orcid.org/0000-0002-0062-0491

\section{Research Article}

Keywords: Soil remediation, phytoremediation, $\mathrm{Cr}, \mathrm{Cd}, \mathrm{Pb}$, accumulation, hyper accumulator

Posted Date: January 25th, 2022

DOI: https://doi.org/10.21203/rs.3.rs-1162609/v1

License: (c) (i) This work is licensed under a Creative Commons Attribution 4.0 International License. Read Full License 


\section{Abstract}

Agricultural soils lose their properties as a result of pollution caused by traffic, industry, agricultural activities, and urban activities. Among various techniques for the remediation of agricultural soils, phytoremediation is the most cost effective and applicable technique. Phyto extraction technique of phytoremediation has been applied with broccoli (Brassica oleracea var. italica) in this study to remediate some heavy metals $(\mathrm{Cd}, \mathrm{Cr}$, and $\mathrm{Pb})$. The study was carried out in controlled conditions in pots according to randomized blocks design using three replicates. Cadmium was applied as only cadmium (30 mg/kg), and together with a chelator as Cd (30 mg/kg) + EDTA, in triplicates. Chromium was applied as only chromium $(10 \mathrm{mg} / \mathrm{kg})$, and together with a chelator as $\mathrm{Cr}(10 \mathrm{mg} / \mathrm{kg})+$ EDTA. Similarly, lead was applied as only lead (100 mg/kg), and together with a chelator as $\mathrm{Pb}(100 \mathrm{mg} / \mathrm{kg})+$ EDTA. After 30 days of incubation, one broccoli was cultivated in each pot. Plants were harvested after 2 months of experimental period. Agro-morphological traits of the plants were measured. Some macro and micro nutrient elements and $\mathrm{Cd}, \mathrm{Cr}$ and $\mathrm{Pb}$ elemental analyses were carried out from root and shoot $\mathrm{pf}$ the plants. Among the agro-morphological traits, plant wet weight was the highest in lead applied pots. This was statistically significant at $5 \%$ and they fell into different groups with control pots according to Duncan test. The highest root and shoot dry weights were detected in lead and chromium applied pots. Changes in chlorophyll contents were found to be statistically insignificant. The highest lead, cadmium and chromium contents in the body of broccoli (Brassica oleracea var. italica) were found to be $14.0 \mathrm{mg} / \mathrm{kg}, 6.67 \mathrm{mg} / \mathrm{kg}$ and, $5.17 \mathrm{mg} / \mathrm{kg}$, respectively, in the chelated applications. The order of accumulation in the root was $\mathrm{Cr}>\mathrm{Pb}>\mathrm{Cd}$. The results revealed that this plant played a role in the remediation of lead>cadmium>chromium as a hyper accumulator plant, and broccoli grown in neutral soils could be used as a hyper accumulator plant in the phytoremediation technology.

\section{Introduction}

Pollution of soil and water sources by toxic heavy metals usually occur as a result of human activities. Technologies for cleaning up soils contaminated by heavy metals require a big capital (Gupta et al. 2013). Phytoremediaiton appears as an economical new technology which can be practically applicated for the elimination of problems caused by pollutants. Phytoremediation has been derived from the words "phyto" which means plant, and "remediation" which means cleaning up; it entered the terminology in 1991 and is defined as "bioremediation", "botanical remediation", and "green remediaition". Phytoremediation is aneasily applied technology to clean up the environment whose basis is formed by accumulator/hyper accumulator plants (Sadowsky 1999; EPA 2000). Hyper accumulator plants are able to accumulate high number of pollutants in their bodies and can accumulate 10-500 times more pollutants compared to other plants (Ow 1996; Adiloğlu et al. 2016; Adiloğlu 2018; Adiloğlu and Pamay 2021).

The heavy metal cadmium (Cd) is a serious pollutant that affects human health. It can be found in different forms depending on the chemical interaction in soil, bioavalaibility, variability and toxicity (Jinadasa et al. 2016; Tanget al. 2016). Cadmium can enter the soil via natural and antropogenic sources. Volcacanic eruptions, forest fires, and rock wheaterings are the natural Cd sources (Khanet al. 2017). Thre is high amount of Cd in mafic and ultramafic rocks. Smelting, wastes of cement production, use of fertilizers with phosphate, ash wastes of fossil fuels are the main antrophological reasons of Cd pollution in soil (Järup 2003; Panet al. 2016). Other Cd sources are plastic stabilizators, batteries, fungicides, wastes of latex and textile productions, motor oil, solar panels and pigments (Khanet al. 2017; Mahmoodet al. 2019). High Cd concentrations casues problems in physiological and biochemical processes in plants. Cd intensity was reported to casue reduction in plant wet weight, leaf length, chlorophyll content, stoma conductivity, seed germination and ATP content (Khanet al. 2017; Rizwanet al. 2017). Cadmium inhibits photosynthesis in plants and causes mitochondrial degradation, therefore inhibits food uptake, delays shoot growth, and casues cell death and chlorosis (Khanet al. 2017). It also interferes with the metabolic processes of the plant, inhibits proton pumps, decreases root growth and harms photosynthetic processes (Mahmoodet al. 2019; Rafiqet al. 2014). 
The heavy metal lead $(\mathrm{Pb})$ can contaminate by many ways, and it has been found to be in a toxic level in the near-road agricultural areas due to traffic. When it enters the cells, it causes toxicity by changin the permability of the cell membrane, reacting with active metabolic enzyme groups, changing essential ions, and forming complex compounds with ADP and ATP. Lead toxicity causes inhibited ezbtme activities, disrupted mineral nutritions, water imbalance, hormonal disturbance, inhibited ATP production, lipid peroxidation, changes in membrane permeability, and DNA damage due to overproduction of reactişve oxygen species (Kumar et al. 2019; Pourrut et al. 2011; Sethy and Ghosh 2013; Sharma and Dubey 2005). Moreover, it reduces photosynthetic acitivty by redcing Calvin cycle enzyme activities, inhibits opening and closing of stomae (Dogan 2019; Adiloğlu ve Sağlam 2015; Adiloğlu 2013; Liuet al. 2008; Mishraet al. 2006; Romanowska et al. 2006; Adiloğlu and Adiloğlu 2003).

Chromium toxicity appears in photosynthesis as inhibition of pigment biosynthesis, photosynthetic electron transfer and Calcin cycle, accelerating lipid peroxidation, and distruption of thylakoid membrane. An in vivo examination of inhibition effects of different doses of chromium $\left(\mathrm{Cr}^{+6}\right)$ on light reactions of photosynthesis of Pisum sativum L. was carried out. The results revelaed inhibition of electron carriage between systems, and affecting the level ol b6f complex levels. The inhibitory effects of $\mathrm{Cr}$ on PSI were more significant than those on PSII. The sensitivity of used kinetic parameters on the functions of photosynthetic reactions was thought to be suitable for the early diagnosis of toxic effects of pollutants on the plants. Many hyperaccumulator plants have been detected for chromium remediation (Todorenko et al. 2020; Dökmeci and Adiloğlu 2020; Adiloğlu and Göker 2021; Adiloğlu et al. 2021).

The family Brassicaceae is an economically important family with its 372 genus and 4060 species. Some members of Brassicaceae are well known hyper accumulators. They have become good candidates for remediation of areas contaminated by various metals/metalloids as they can translocate high amounts of metals from roots to the shoots without a phytotoxic symptom. These plants tolerate by partitioning higher amounts of heavy metals in the vacuoles of the above soil parts. This is carried out by excess expression of some metal carriers in different tissues and affects the storage in the leaves.Studies to understand the hyperaccumulatin and hyper tolerance characteristics related with Brassicaceae, gathering of metals and detoxification have been carried out (Daud et al. 2018). The useage of hyperaccumulators results in low biomass rich in metals, which is an easy and economic way of metal recovery and safe elimination. On the other hand, use of non accumulators result in an expensive to safely eradicate, non economical processing to recover metals, large biomass with poor metal accumulation. Many accumulator plants used in the remediation of heavy metals are members of Brassicaceae family (Adiloğlu 2016; Adiloğlu 2018; Adiloğlu and Gürgan 2020; Adiloğlu and Pamay 2021).

There is a need for inexpensive and efficient biological solutions for the problem of heavy metal contamination of agricultural soils. Phytoremediation is the leading of such solutions. The choice of hyperaccumulator plant is very important for this method. That is why in this study the the accumulator capacity of Broccoli (Brassica oleracea var. italica) for the remediation of soil contaminated by chromium, lead and cadmium was evaluated.

\section{Materials And Methods}

The soil was taken from 0-30 $\mathrm{cm}$ depth. It was air dried, minced and sifted through a $4 \mathrm{~mm}$ sieve, and put into the pots. The trial was carried out inthe labs of Soil Science and Plant Nutrition Department, Faculty of AgricultureTekirdağ Namık Kemal University, according to Randomized Blocks Design with triplicates. Three contaminants were used as $\mathrm{CdSO}_{4}$, $\mathrm{Cr}\left(\mathrm{NO}_{3}\right)_{3}$ and $\mathrm{Pb}\left(\mathrm{NO}_{3}\right)_{2}$ in the amounts of $30 \mathrm{mgkg}^{-1} \mathrm{Cd}, 10 \mathrm{mgkg}^{-1} \mathrm{Cr}(\mathrm{IV})$ and $100 \mathrm{mgkg}^{-1} \mathrm{~Pb}$, respectively. Constant amount of chelator (10 mmol/kg EDTA) were applied to each contaminant dose in order to increase the solubility. The plants were kept at controlled conditions at $22^{\circ} \mathrm{C}$ with an availability of sun light. After 30 days of incubation to naturally pollute the soil and absoroption of pollutants by soil colloids, soil samples were taken from each pot and extractable Cd, $\mathrm{Cr}$ and $\mathrm{Pb}$ analyses were done. A picture from the experiment is given in Figure 1. 


\section{Plant analyses}

Some agro morphological traits of Broccoli (Brassica oleracea var. italica) harvested the trial were determined (Jones et al. 1991). Plants were dried at $65^{\circ} \mathrm{C}$ for 48 hours to determine the plant dry weight (Kacar and İnal, 2010). Extraction was carried out at lab conditions according to EPA 3052 wet burning metahod with microwave (EPA, 1996), and elemental analyses were carried out by ICP-OES (Inductively Couple Plasma Spectrophotometer).

\section{Soil analyses}

Soil samples brought to lab were air dried and sieved with $2 \mathrm{~mm}$ sieve before analyses.

- $\mathrm{pH}$ of soil samples was measured in $1 / 2.5$ soil/water mixture according to Jackson (1967).

- Lime content of the soils was determined volumetrically with Scheibler calcimeter (Sağlam 2012).

- Electrical conductivity was measured in 1/2.5 soil/water mixture with EC meter (Sağlam 2012).

- Texture fractions of the study soil were done according to Bouyoucos Hydrometer method (Bouyoucos 1955).

- Organic matter content was determined according to Walkey-Black method (Kacar 1995).

- Available phosphorus was determined according to Olsen method (Olsen 1982).

- Changeable potassium content was determined with $1 \mathrm{~N}$ Ammonium Acetate (pH 7) method (Kacar 1995).

- Extractable Fe, Zn, Cu and Mn analyses were carried out according to DTPA method (0.005 M DTPA+ 0.1 M TEA+ 0.01 $\mathrm{M} \mathrm{CaCl}_{2}$ ) (Lindsay and Norwell 1978).

\section{Some extractable heavy metals}

For the analysis of some extractable heavy metals $0.005 \mathrm{M} \mathrm{DTPA}+0.01 \mathrm{M} \mathrm{CaCl}_{2}+0.1 \mathrm{M} \mathrm{TEA}(\mathrm{pH}$ 7.3) was used (Lindsay ve Norvell, 1978) and $\mathrm{Cr}$, Cd and Pb amounts were detected by ICP-OES.

\section{Statistical analyses}

Variance analyses were carried out for plant agro morphological traits, nutrition elements and heavy metals in plants and soils, and significant mean values were subjected to Duncan multiple comparison tets in SPSS-17 package program.

\section{Results And Discussion}

Some chemical data of the experimental soil showed that the soil pH was neutral. The soil was insufficient in terms of organic matter. This situation is positive for this experiment. Because high organic matter in the soil can inactivate contaminats and can inhibit the uptake of them by the plants (Adiloğlu and Sağlam 2015). The lime content was medium, phosphorus and potassium were sufficient in the soil. Available Fe and Mn contents were found to below while $\mathrm{Zn}$ and $\mathrm{Cu}$ contents were sufficient. Extractable $\mathrm{Cr}$, $\mathrm{Cd}$ and $\mathrm{Pb}$ contents were lower than the toxic level. Some chemical and physical properties of the research soil are given in Table 1. 
Table 1

Some physical and chemical datas of the experimental soil

\begin{tabular}{|c|c|c|}
\hline Soil properties & Unit & Value \\
\hline $\mathrm{pH}$ & $\star \star *$ & 6.78 \\
\hline Electrical Conductivity & * & 0.23 \\
\hline $\mathrm{CaCO}_{3}$ & * & 8.89 \\
\hline Organic matter & * & 1.85 \\
\hline Available $\mathrm{P}_{2} \mathrm{O}_{5}$ & ** & 41.48 \\
\hline Exchangeable $\mathrm{K}_{2} \mathrm{O}$ & ** & 230.25 \\
\hline $\mathrm{Fe}$ & ** & 0.20 \\
\hline Available Cu & $\star \star$ & 0.69 \\
\hline AvailableZn & $\star *$ & 0.70 \\
\hline Available Mn & ** & 1.65 \\
\hline Cr content & $\star *$ & 0.09 \\
\hline Cd content & $\star *$ & 0.05 \\
\hline $\mathrm{Pb}$ content & $\star \star$ & 0.37 \\
\hline Clay & * & 20 \\
\hline Silt & * & 29 \\
\hline Sand & * & 51 \\
\hline Texture Class & - & Sandy Loam (SL) \\
\hline
\end{tabular}

Change in some agro-morphological traits of Broccoli (Brassica oleracea var. italica)

Some agro morphological traits of Broccoli (Brassica oleracea var. Italica) used in the experiments and grown on soils contaminated by $30 \mathrm{mgkg}^{-1} \mathrm{Cd}, 10 \mathrm{mgkg}^{-1} \mathrm{Cr}$ IV and $100 \mathrm{mgkg}^{-1} \mathrm{~Pb}$ are given in Table 2 . 
Table 2

Some agro-morphological measurements* of Broccoli (Brassica oleracea var. italica)

\begin{tabular}{|c|c|c|c|c|c|c|c|}
\hline Data & Control & ${ }^{+}$Cd+EDTA & $\mathrm{Cd}$ & ${ }^{++} \mathrm{Pb}+\mathrm{EDTA}$ & $\mathrm{Pb}$ & ${ }^{+++} \mathrm{Cr}+\mathrm{EDTA}$ & $\mathrm{Cr}$ \\
\hline $\begin{array}{l}\text { Shoot } \\
\text { WW g }\end{array}$ & $22.3 \pm 1.2 b$ & $19.0 \pm 6.2 b$ & $28.4 \pm 7.5 \mathrm{ab}$ & $40.2 \pm 10.9 a b$ & $48.3 \pm 6.9 a$ & $36.2 \pm 4.8 a$ & $39.8 \pm 3.9 a b$ \\
\hline $\begin{array}{l}\text { Root } \\
\text { WW g }\end{array}$ & $2.03 \pm 0.2 \mathrm{abc}$ & $1.20 \pm 0.2 c$ & $1.63 \pm 0.3 c$ & $2.0 \pm 0.4 a b c$ & $3.6 \pm 0.2 \mathrm{ab}$ & $1.83 \pm 0.2 b c$ & $3.23 \pm 0.2 \mathrm{a}$ \\
\hline $\begin{array}{l}\text { Plant } \\
\text { length } \\
\mathrm{cm}\end{array}$ & $35.33 \pm 0.8 \mathrm{~ns}$ & $30.30 \pm 1.3 \mathrm{~ns}$ & $33.33 \pm 3.7 n s$ & $39.6 \pm 0.8 \mathrm{~ns}$ & $39.7 \pm 3.5 n s$ & $36.30 \pm 1.2 \mathrm{~ns}$ & $39.6 \pm 0.8 \mathrm{~ns}$ \\
\hline $\begin{array}{l}\text { Root } \\
\text { length } \\
\mathrm{cm}\end{array}$ & $13 \pm 2,0 \mathrm{bc}$ & $11 \pm 0,1 c$ & $15 \pm 2.3 a b c$ & $13 \pm 0.0 \mathrm{bc}$ & $17 \pm 0.5 a b$ & $12.66 \pm 1.6 b c$ & $18.66 \pm 2.3 a$ \\
\hline SPAD & $52.4 \pm 2.5 \mathrm{~ns}$ & $49.56 \pm 2.3 \mathrm{~ns}$ & $49.66 \pm 4.6 n s$ & $57.41 \pm 1.6 \mathrm{~ns}$ & $57.43 \pm 3.1 \mathrm{~ns}$ & $52.33 \pm 3.9 \mathrm{~ns}$ & $58.6 \pm 4.2 \mathrm{~ns}$ \\
\hline $\begin{array}{l}\text { Shoot } \\
\text { DW g }\end{array}$ & $8.15 \pm 0.01 c$ & $7.49 \pm 0.7 c$ & $8.19 \pm 0.5 c$ & $9.5 \pm 1.01 \mathrm{abc}$ & $10.82 \pm 0.9 a b$ & $8.46 \pm 0.4 b c$ & $11.3 \pm 1.1 \mathrm{a}$ \\
\hline $\begin{array}{l}\text { Root } \\
\text { DW g }\end{array}$ & $2.03 \pm 0.2 a b c$ & $1.2 \pm 0.2 \mathrm{c}$ & $5.17 \pm 0.3 c$ & $5.2 \pm 0.4 a b c$ & $5.5 \pm 0.2 \mathrm{ab}$ & $1.83 \pm 0.2 b c$ & $3.23 \pm 0.7 a$ \\
\hline $\begin{array}{l}\text { Number } \\
\text { leaves }\end{array}$ & $17.3 \pm 1.45 a b$ & $14.00 \pm 2.00 \mathrm{~b}$ & $17.00 \pm 2.3$ & $17.3 \pm 0.8 a$ & $20.6 \pm 1.6 a b$ & $18.66 \pm 1.2 \mathrm{ab}$ & $19.6 \pm 2.2 \mathrm{ab}$ \\
\hline
\end{tabular}

The applied contaminants did not negatively affect the chlorophyll contents of the plant (Table 2). It is seen that the plant physiologically defended itself by accumulating heavy metals in its body and also changed the cental $\mathrm{Mg}$ atom in the chlorophyll so that heavy metals could not affect the chlorophyll (Karaman et al. 2012). Negative effects of Pb, $\mathrm{Cd}$ and $\mathrm{Cr}$ were shown on mnay plants in the literature. Cadmium was shown to inhibit photosynthesis in Brassica napus, Helianthus annus, Thlaspica erulescens, Zea mays, Pisum sativum, Hordeum vulgare, Vignar adiata and Triticum which were exposed to Cd toxicity (Baryla et al. 2001; DiCagno et al. 2001; Küpper et al. 2007; Moussa and El-Gamal 2010; Popova et al. 2008; Wahid et al. 2008). The accumulation of lead in the plants has many direct or indirect effects on morphological, physiological and biochemical funcitons of the plants. The typical symptoms of lead toxicity are inhibition of photosynthetic pigment content and photosynthetic activity (Singh et al. 2010). Increasing doses of chromium application were shown to decrease dry weight in corn (Zea mays L.) (Adiloğlu and Göker 2021).

Accumulation of some contaminants ( $\mathrm{Cr}, \mathrm{Cd}, \mathrm{Pb})$ in the roots and shoot of Broccoli (Brassica oleracea var. italica) and contents of contaminants in the soil after the harvest

Remediation of $\mathrm{Cd}, \mathrm{Pb}$ and $\mathrm{Cr}$ pollutants and accumulation in Broccoli (Brassica oleracea var. italica) are given in Table 3. The accumulation of $\mathrm{Pb}$ and $\mathrm{Cd}$ are in plant body is higher in pots treated with chelator compared to the control pots. This is the result of increased available form of pollutants in the soil solution. Although there is not a significant difference between control and $\mathrm{Cr}$ applied with chelator pots, there is a great numerical difference. Broccoli was therefore shown to accumulate chromium pollutants in its body depending on the concentration. 
Table 3

Some heavy metal $(\mathrm{Cr}, \mathrm{Cd}, \mathrm{Pb})$ measurements of Broccoli

(Brassica oleracea var. Italica) and soil, $\mathrm{mgkg}^{-1}$

\begin{tabular}{|llll|}
\hline Doses & Plant shoot & Plant root & Soil \\
\hline Control- Cd & $0.28 \pm 0.2 \mathrm{c}$ & $0.81 \pm 0.01 \mathrm{c}$ & $0.05 \pm 0.01 \mathrm{c}$ \\
\hline${ }^{*} \mathrm{Cd}$ & $4.53 \pm 0.9 \mathrm{~b}$ & $5.41 \pm 0.09 \mathrm{~cd}$ & $17.7 \pm 0.03 \mathrm{a}$ \\
\hline${ }^{*} \mathrm{Cd}+\mathrm{EDTA}$ & $6.67 \pm 1.9 \mathrm{a}$ & $7.8 \pm 0.08 \mathrm{a}$ & $6.30 \pm 0.02 \mathrm{~b}$ \\
\hline Control- Pb & $0.97 \pm 0.08 \mathrm{~cd}$ & $1.43 \pm 0.15 \mathrm{~d}$ & $0.37 \pm 0.1 \mathrm{e}$ \\
\hline${ }^{* *} \mathrm{~Pb}$ & $6.80 \pm 0.09 \mathrm{~d}$ & $5.91 \pm 0.10 \mathrm{~b}$ & $13.10 \pm 0.1 \mathrm{~g}$ \\
\hline${ }^{* *} \mathrm{~Pb}+\mathrm{EDTA}$ & $14.0 \pm 0.09 \mathrm{ab}$ & $10.68 \pm 0.29 \mathrm{a}$ & $19.08 \pm 0.2 \mathrm{f}$ \\
\hline $\mathrm{Control}-\mathrm{Cr}$ & $0.56 \pm 0.5 \mathrm{~d}$ & $3.43 \pm 0.03 \mathrm{~d}$ & $0.09 \pm 0.1 \mathrm{c}$ \\
\hline${ }^{* * *} \mathrm{Cr}$ & $5.17 \pm 0.3 \mathrm{~b}$ & $15.79 \pm 0.45 \mathrm{~b}$ & $0.78 \pm 0.3 \mathrm{~b}$ \\
\hline${ }^{* * *} \mathrm{Cr}+\mathrm{EDTA}$ & $5.75 \pm 0.2 \mathrm{a}$ & $17.74 \pm 3.37 \mathrm{a}$ & $1.10 \pm 0.2 \mathrm{a}$ \\
\hline${ }^{*} \mathrm{Cd}: 30 \mathrm{mgkg}{ }^{-1}{ }^{* *} \mathrm{~Pb}: 100 \mathrm{mgkg}^{-1}{ }^{* \star *} \mathrm{Cr}^{\circ} 10 \mathrm{mgkg}^{-1}$ \\
\hline
\end{tabular}

The accumulation of lead pollutant in plant shoots rather than roots in the pots where lead was applied drove attention in Table 3. The other pollutants accumulated more in the plant roots as expected. The plants which can accumulate pollutants in their above ground parts are more preferred in phytoremediation, therefore broccoli (Brassica oleracea var. italica) was revealed to be employed in the remediation of lead.

Cadmium (Cd) toxicity affects the photosystem II (PS II) (Baker 1991) and stress damage can be easily detected by chlorophyll change in fluorescent structures (Maxwell and Johnson 2000). Ribulose-1,5 diphosphate carboxylase (BuBisCo) and phosphoenol pyruvate carboxylase, the two enzymes that take place in $\mathrm{CO}_{2}$ fixation, are the main targets of $\mathrm{Cd}$. It reduces the activity of RuBisCoby changing its structure, by changing the Mg ion which is the vital cofactor of carboxylation reactions, and by directing the $\mathrm{Mg}$ ions to oxidation reactions (Shanmugarajet al. 2019). Water oxidation complex of photosystem II is affected by the modifications of $\mathrm{Qb}$ binding sites and replacement of $\mathrm{Ca}^{2+}$ in $\mathrm{Ca} / \mathrm{Mn}$ clusters. Stimulation of calmodulin likes proteins by structural changes to regulate mechanisms such as gene regulations, stress tolerance, ion exchange by interacting with $\mathrm{Ca}^{2+}$ ions significantly increase during $\mathrm{Cd}$ stress. Concentration significantly increases during of Cd stress (Geikenet al. 1998; Yang andPoovaiah 2003; Sigfridssonet al. 2004; DalCorsoet al. 2008; Shanmugarajet al. 2019).

Various physiological of plants such as the transpiration ratio, stoma movements, plant water absorbtion, enzyme activity, seed germination, protein synthesis in plant, cell membrane stability, hormonal balance of the plant are negatively affected by chromium contamination (Asri and Sönmez 2006).

Salidoet al. (2003) employed Chinese fern (Pteris vittata L.) and Indian mustard (Brassica juncea L.) as the accumulator plants in a study to investigate the phytoremediation of arsenic and lead contamination. The absorption of arsenic and lead were shown to increase by the application of EDTA. As a result, they revealed that as and Pb pollution in soil can be inhibited vy the phytoremediation method.

Effects of some contaminats ( $\mathrm{Cr}, \mathrm{Cd}, \mathrm{Pb}$ ) accumulated in the shoots of Broccoli (Brassica oleracea var. italica) on some macro and micro nutrient elements 
Change in the macro and micro nutrient elements which are vital for plant development in broccoli plant (Brassica oleracea var. italica) during the remediation of $\mathrm{Cd}, \mathrm{Pc}$ and $\mathrm{Cr}$ heavy metals from the soil used in the research are given in Table 4 . A significant decrease in macro and micro nutrient elements in the pots where chromium was applied together with the chelator was observed. Copper and zinc among micro nutrient elements were especially found to increase in the case of lead pollution. The reason of this situation is thought to be increased solubility of these micro elements due to EDTA chelator application. Moreover, a synergistic effect might have occurred between these elements. The other pollutant cadmium positively affected all plant macro elements except $\mathrm{Mg}$ significantly at $5 \%$ significance level, and the elements fell into different groups in Duncan test. A synergistic effect among all the micro nutrient elements was observed in plants grew in both cadmium and Cd+EDTA applied pots. That is why the plants continued to develop and were not affected from the contaminats that took up into their bodies.

Calcium is absolutely required for synthesis of cell wall and development of the plants. Approximately $90 \%$ of Ca is present in cell walls. It behaves as the cohesion factor for cell binding and keeping the structures together in plant tissues. In case of Ca insufficiency, new tissue generation in roots and shoots slow down. As a result, the productivity of the plant is adversely affected. Calcium is also one of the keystones of plant defense mechanism and helps the recognition and reaction to stress elements. Since calcium is not mobile in plants, the insufficiency symptoms first appear in young leaves and and young tissues are the first to be damaged by insufficiency of calcium (Karaman et al. 2012).

Table 4

Effects of some contaminats $(\mathrm{Cr}, \mathrm{Cd}, \mathrm{Pb})$ accumulated in the shoots of Broccoli (Brassica oleracea var. italica) on some macro and micro nutrient elements

\begin{tabular}{|llllllll|}
\hline Doses & Control & ${ }^{*} \mathrm{Cd}$ & ${ }^{*} \mathrm{Cd}+\mathrm{EDTA}$ & ${ }^{* *} \mathrm{~Pb}$ & ${ }^{* *} \mathrm{~Pb}+\mathrm{EDTA}$ & ${ }^{* * *} \mathrm{Cr}$ & ${ }^{* *} \mathrm{Cr}+\mathrm{EDTA}$ \\
\hline $\mathrm{P}^{+}$ & $0.11 \pm 2.7 \mathrm{e}$ & $0.09 \pm 3.5 \mathrm{f}$ & $0.16 \pm 12.5 \mathrm{~b}$ & $0.15 \pm 8.7 \mathrm{~d}$ & $0.21 \pm 11.5 \mathrm{a}$ & $0.20 \pm 3.5 \mathrm{a}$ & $0.16 \pm 3.07 \mathrm{c}$ \\
\hline $\mathrm{K}^{+}$ & $1.66 \pm 0.1 \mathrm{~d}$ & $1.56 \pm 2.6 \mathrm{e}$ & $2.02 \pm 2.8 \mathrm{a}$ & $1.75 \pm 2.6 \mathrm{c}$ & $2.47 \pm 0.3 \mathrm{a}$ & $1.84 \pm 2.6 \mathrm{~b}$ & $1.68 \pm 4.9 \mathrm{~d}$ \\
\hline $\mathrm{Ca}^{+}$ & $1.65 \pm 0.6 \mathrm{c}$ & $1.57 \pm 2.0 \mathrm{~d}$ & $1.89 \pm 2.7 \mathrm{~b}$ & $1.97 \pm 2.5 \mathrm{a}$ & $1.17 \pm 1.1 \mathrm{~g}$ & $1.50 \pm 1.1 \mathrm{e}$ & $1.25 \pm 0.6 \mathrm{f}$ \\
\hline $\mathrm{Mg}^{+}$ & $0.20 \pm 2.6 \mathrm{a}$ & $0.20 \pm 2.1 \mathrm{ab}$ & $0.19 \pm 2.9 \mathrm{c}$ & $0.19 \pm 1.3 \mathrm{bc}$ & $0.17 \pm 1.6 \mathrm{e}$ & $0.17 \pm 1.4 \mathrm{~d}$ & $0.15 \pm 1.1 \mathrm{f}$ \\
\hline $\mathrm{Fe}^{++}$ & $19.05 \pm 0.1 \mathrm{e}$ & $22.6 \pm 0.3 \mathrm{~b}$ & $34.15 \pm 0.4 \mathrm{a}$ & $29.75 \pm 0.3 \mathrm{~b}$ & $18.55 \pm 0.2 \mathrm{e}$ & $24.3 \pm 0.2 \mathrm{e}$ & $9.05 \pm 0.1 \mathrm{f}$ \\
\hline $\mathrm{Cu}^{++}$ & $2.85 \pm 0.04 \mathrm{f}$ & $2.68 \pm 0.03 \mathrm{~g}$ & $4.28 \pm 0.02 \mathrm{a}$ & $3.57 \pm 0.03 \mathrm{~d}$ & $4.14 \pm 0.03 \mathrm{~b}$ & $3.98 \pm 0.03 \mathrm{c}$ & $3.14 \pm 0.01 \mathrm{e}$ \\
\hline $\mathrm{Zn}^{++}$ & $16.8 \pm 0.02 \mathrm{e}$ & $13.56 \pm 0.1 \mathrm{f}$ & $23.8 \pm 0.2 \mathrm{~b}$ & $22.8 \pm 0.2 \mathrm{c}$ & $24.1 \pm 0.08 \mathrm{~b}$ & $29.4 \pm 0.2 \mathrm{a}$ & $22.3 \pm 0.1 \mathrm{~d}$ \\
\hline $\mathrm{Mn}^{++}$ & $22.6 \pm 0.01 \mathrm{e}$ & $13.8 \pm 0.02 \mathrm{~g}$ & $46.8 \pm 0.05 \mathrm{~b}$ & $41.5 \pm 0.1 \mathrm{c}$ & $19.6 \pm 0.3 \mathrm{f}$ & $51.6 \pm 0.1 \mathrm{a}$ & $26.9 \pm 0.2 \mathrm{~d}$ \\
\hline $\mathrm{B}^{++}$ & $19.3 \pm 0.6 \mathrm{f}$ & $14.2 \pm 0.5 \mathrm{~g}$ & $35.06 \pm 0.3 \mathrm{a}$ & $31.4 \pm 0.1 \mathrm{~b}$ & $22.6 \pm 0.04 \mathrm{e}$ & $28.6 \pm 0.1 \mathrm{c}$ & $23.5 \pm 0.1 \mathrm{~d}$ \\
\hline${ }^{*} \mathrm{Cd}: 30 \mathrm{mgkg}{ }^{-1} \mathrm{~Pb}: 100 \mathrm{mgkg}{ }^{-1 * *} \mathrm{Cr}: 10 \mathrm{mgkg}{ }^{-1}+: \%++: \mathrm{mgkg}^{-1}$ & & & \\
\hline
\end{tabular}

Cadmium (Cd) affects the transport functions of macro and micro nutrient elements by reducing absoption. Cd harms absorption, transport and distribution of macro and micro nutrient elements such as $\mathrm{Ca}, \mathrm{Mg}, \mathrm{P}, \mathrm{K}, \mathrm{S}, \mathrm{Fe}, \mathrm{Mo}, \mathrm{Zn}, \mathrm{B}$, and Cu in plants like sugar beet, pea and barley (Hernández et al. 1996; Chang et al. 2003; Metwally et al. 2005; Guo et al. 2007; Adiloğlu 2017; Shanmugaraj et al. 2019; Adiloğlu 2020; Adiloğlu 2021).

The reduction in the photosynthetic activity in plants exposed to lead is a result of destruction of chlorophyll subunits, inhibition of plastoquinone and carotenoid synthesis, deficiency in basic elements such as Mn and Fe, substitution of bivalent cations with Pb, and destruction of electron transport system (Pourrut et al. 2011; Sharma and Dubey 2005). 
According to Wallace et al. (1976) Cr contents in chromium accumulating plants are really high. For instance, Cr content in the leaves of $\mathrm{Cr}$ toxicated plants were $1-4 \mathrm{mg} / \mathrm{kg}$, and even more in the roots.

Effects of some contaminats $(\mathrm{Cr}, \mathrm{Cd}, \mathrm{Pb})$ accumulated in the roots of Broccoli (Brassica oleracea var. italica) on some macro and micro nutrient elements

The interactions and accumulation of heavy metals in the Broccoli (Brassica oleracea var. italica) in roots with the absolutely required macro and micro nutrient elements are given in Table 5.

Table 5

Accumulation of $\mathrm{Cd}, \mathrm{Pb}$ and $\mathrm{Cr}$ pollutants in the roots of broccoli and effects on some nutrient elements

\begin{tabular}{|c|c|c|c|c|c|c|c|}
\hline Doses & Control & ${ }^{*} \mathrm{Cd}$ & ${ }^{*} \mathrm{Cd}+\mathrm{EDTA}$ & ${ }^{* \star} \mathrm{Pb}$ & ${ }^{* *} \mathrm{~Pb}+\mathrm{EDTA}$ & ${ }^{* *} \mathrm{Cr}$ & ${ }^{\star * \star} \mathrm{Cr}+\mathrm{EDTA}$ \\
\hline $\mathrm{P}^{+}$ & $0.07 \pm 2.4 f$ & $0.07 \pm 3.0 \mathrm{e}$ & $0.84 \pm 3.9 d$ & $0.10 \pm 2.4 b$ & $0.09 \pm 2.3 b$ & $0.14 \pm 1.9 a$ & $0.10 \pm 1.27 c$ \\
\hline $\mathrm{K}^{+}$ & $1.03 \pm 0.5 d$ & $1.12 \pm 6.5 \mathrm{c}$ & $1.11 \pm 5.0 \mathrm{c}$ & $1.30 \pm 1.3 b$ & $1.28 \pm 1.3 b$ & $1.43 \pm 1.4 a$ & $0.90 \pm 0.5 \mathrm{e}$ \\
\hline $\mathrm{Ca}^{+}$ & $0.42 \pm 0.4 \mathrm{e}$ & $0.36 \pm 1.8 f$ & $0.79 \pm 0.1 b$ & $0.36 \pm 3.6 f$ & $0.47 \pm 0.5 d$ & $0.52 \pm 0.3 c$ & $1.27 \pm 1.3 a$ \\
\hline $\mathrm{Mg}^{+}$ & $0.14 \pm 0.10 c$ & $0.15 \pm 1.8 b$ & $0.12 \pm 0.1 d$ & $0.10 \pm 0.17 e$ & $0.12 \pm 8.4 d$ & $0.09 \pm 0.9 b$ & $0.16 \pm 1.3 a$ \\
\hline $\mathrm{Fe}^{++}$ & $570 \pm 0.4 \mathrm{~g}$ & $1179 \pm 0.36 c$ & $1406 \pm 0.9$ & $635 \pm 2.7 f$ & $1041 \pm 5.08 d$ & $966 \pm 8.6 \mathrm{e}$ & $3895 \pm 31.2 a$ \\
\hline $\mathrm{Cu}^{++}$ & $5.36 \pm 0.04 f$ & $6.4 \pm 0.01 d$ & $10.9 \pm 0.10 b$ & $5.97 \pm 0.07 e$ & $6.14 \pm 0.01 \mathrm{e}$ & $7.15 \pm 0.04 c$ & $15.1 \pm 0.07 a$ \\
\hline $\mathrm{Zn}^{++}$ & $13.6 \pm 0.01 d$ & $10.4 \pm 0.09 e$ & $19.7 \pm 0.06 b$ & $17.5 \pm 0.08 c$ & $17.6 \pm 0.05 c$ & $19.8 \pm 0.1 b$ & $28.06 \pm 0.2 a$ \\
\hline $\mathrm{Mn}^{++}$ & $32.1 \pm 0.08 f$ & $47.7 \pm 0.3 d$ & $85.9 \pm 0.3 b$ & $42.3 \pm 0.3 e$ & $43.4 \pm 0.1 \mathrm{e}$ & $67.8 \pm 0.3 c$ & $20.0 \pm 1.7 a$ \\
\hline $\mathrm{B}^{++}$ & $12.6 \pm 0.5 \mathrm{e}$ & $12.8 \pm 0.11 \mathrm{e}$ & $19.7 \pm 0.06 b$ & $14.7 \pm 0.03 d$ & $15.6 \pm 0.1 \mathrm{c}$ & $15.0 \pm 0.2 d$ & $23.2 \pm 0.04 a$ \\
\hline
\end{tabular}

There was a significant increase of the macro nutrient elements except potassium and phosphorus, and micro elements except manganese in the pots where chromium was applied together wih the chelator. Increases in the amounts of all macro and micro nutrietnts except potassium were observed in the case of lead pollution. The reason of this situation is thought to be increased solubility of these micro elements due to EDTA chelator application. Moreover, a synergistic effect might have occurred between these elements. The other pollutant cadmium positively affected all plant macro elements except Ca significantly at $5 \%$ significance level, and the elements fell into different groups in Duncan test. A synergistic effect among all the micro nutrient elements except Zn was observed in plants grew in cadmium and Cd+EDTA applied pots. That is why the plants continued to develop and were not affected from the contaminats thet took up into their bodies.

When chromium $\left(\mathrm{Cr}^{+6}\right)$ enters the root cell, it is easily reduced to $\mathrm{Cr}$ (III) form by the Fe (III) reductase enzyme. Since chromium immobilizes in the voids of root cells, a high Cr accumulation is observed in roots (Adhikari et al. 2020; Hayat et al. 2012). Chromium $\left(\mathrm{Cr}^{+6}\right)$ toxicity can change enzyme activities, reduce resistance to pathogenic organisms, causes changes in behaviouralmodificaitons, population structure and species diversity and inhibition of photosynthesis (Pradhan et al. 2019; Sethuraman and Balasubramanian 2010). If chromium $\left(\mathrm{Cr}^{+6}\right)$ accumulation in plants exceeds metabolic capacity for detoxification, seed germination, root and shoot development and biomass production slow down (Hayat et al. 2012; Sharma and Dubey 2005). Moreover, chromium $\left(\mathrm{Cr}^{+6}\right)$ affects nutrient uptake and interferes with antioxidant systems and intercellular membrane structures. This metal harms the photosytnethic process as it decreases lipid peroxidation in proteins and photosynthetic pigments, (Diwan et al. 2012; Panda and Choudhury 2005; Singh et al. 2013; 
Vajpayee et al. 2000). Electron transport, $\mathrm{CO}_{2}$ fixaiton and photophosphorylation are affected by chromium ( $\left.\mathrm{Cr}^{+6}\right)(\mathrm{Ali}$ et al . 2006; Diduret al. 2013; Mathur et al. 2016; Pandey et al. 2013; Susplugas et al. 2000; van Assche and Clijsters 1983).

In root filtration method, pollutants adsorb to the roots or taken by the roots depending on the biotic and abiotic processes. During these processes, pollutants can be uptaken by the soils and can be transported. The immobilization of pollutants on or in the roots is substantial at this point. The pollutants can later be extracted from the plants by various methods. This method can be applied to underground waters, ground wasters and wastewaters (Adiloğlu 2021).

\section{Effects of some contaminants $(\mathrm{Cr}, \mathrm{Cd}$, and $\mathrm{Pb}$ ) on some macro and micro nutrient elements in soil where Broccoli (} Brassica oleracea var. italica) was grown

The effects of contaminats and EDTA chelator on some macro and micro nutrient elements in the soils are given in Table 6.

Table 6

Accumulation and effects of $\mathrm{Cd}, \mathrm{Pb}$ and $\mathrm{Cr}$ on some plant nutrient elements in soil where broccoli was grown

\begin{tabular}{|llllllll|}
\hline Doses & Control & ${ }^{*} \mathrm{Cd}$ & ${ }^{*} \mathrm{Cd}+\mathrm{EDTA}$ & ${ }^{* *} \mathrm{~Pb}$ & ${ }^{* *} \mathrm{~Pb}+\mathrm{EDTA}$ & ${ }^{* * *} \mathrm{Cr}$ & ${ }^{* * *} \mathrm{Cr}+\mathrm{EDTA}$ \\
\hline $\mathrm{P}^{+}$ & $37.1 \pm 0.2 \mathrm{c}$ & $31.8 \pm 0.3 \mathrm{e}$ & $23.1 \pm 0.2 \mathrm{f}$ & $33.4 \pm 0.4 \mathrm{~d}$ & $41.9 \pm 0.3 \mathrm{a}$ & $38.2 \pm 0.1 \mathrm{~b}$ & $41.3 \pm 1.3 \mathrm{a}$ \\
\hline $\mathrm{K}^{+}$ & $1.37 \pm 0.32$ & $1.34 \pm 0.7 \mathrm{~b}$ & $1.17 \pm 0.4 \mathrm{~d}$ & $1.24 \pm 0.7 \mathrm{c}$ & $1.16 \pm 1.9 \mathrm{~d}$ & $1.42 \pm 1.1 \mathrm{a}$ & $1.36 \pm 0.9 \mathrm{~b}$ \\
\hline $\mathrm{Ca}^{+}$ & $39.4 \pm 4.1 \mathrm{~b}$ & $46.5 \pm 7.3 \mathrm{a}$ & $37.8 \pm 8.2 \mathrm{c}$ & $39.4 \pm 3.8 \mathrm{~b}$ & $37.5 \pm 4.9 \mathrm{c}$ & $38.3 \pm 2.9 \mathrm{bc}$ & $37.2 \pm 4.8 \mathrm{c}$ \\
\hline $\mathrm{Mg}^{+}$ & $2.92 \pm 6.8 \mathrm{c}$ & $3.22 \pm 4.5 \mathrm{a}$ & $2.70 \pm 3.2 \mathrm{~d}$ & $2.73 \pm 2.1 \mathrm{~d}$ & $2.8 \pm 3.5 \mathrm{~cd}$ & $2.81 \pm 1.1 \mathrm{~cd}$ & $3.12 \pm 4.1 \mathrm{~b}$ \\
\hline $\mathrm{Fe}^{++}$ & $9.3 \pm 0.5 \mathrm{c}$ & $12.5 \pm 0.7 \mathrm{~b}$ & $7.37 \pm 0.3 \mathrm{e}$ & $7.5 \pm 0.02 \mathrm{e}$ & $12.5 \pm 0.4 \mathrm{~b}$ & $8.1 \pm 0.02 \mathrm{~d}$ & $15.2 \pm 0.6 \mathrm{a}$ \\
\hline $\mathrm{Cu}^{++}$ & $1.01 \pm 0.1 \mathrm{~d}$ & $1.08 \pm 1.8 \mathrm{a}$ & $0.9 \pm 0.1 \mathrm{e}$ & $1.07 \pm 0.2 \mathrm{a}$ & $1.03 \pm 0.1 \mathrm{c}$ & $1.06 \pm 0.1 \mathrm{~b}$ & $1.03 \pm 0.2 \mathrm{c}$ \\
\hline $\mathrm{Zn}^{++}$ & $0.95 \pm 0.1 \mathrm{~d}$ & $1.10 \pm 0.1 \mathrm{~b}$ & $0.7 \pm 0.1 \mathrm{f}$ & $0.9 \pm 0.1 \mathrm{e}$ & $1.16 \pm 0.2 \mathrm{a}$ & $0.97 \pm 0.1 \mathrm{~d}$ & $1.03 \pm 0.1 \mathrm{c}$ \\
\hline $\mathrm{Mn}^{++}$ & $13.1 \pm 0.1 \mathrm{f}$ & $25.8 \pm 0.15 \mathrm{a}$ & $14.9 \pm 0.1 \mathrm{e}$ & $15.3 \pm 0.2 \mathrm{~d}$ & $20.0 \pm 0.4 \mathrm{~b}$ & $16.0 \pm 0.6 \mathrm{c}$ & $17.8 \pm 0.9 \mathrm{~b}$ \\
\hline $\mathrm{B}^{++}$ & $0.26 \pm 0.1 \mathrm{~d}$ & $0.31 \pm 0.1 \mathrm{bc}$ & $0.29 \pm 0.1 \mathrm{c}$ & $0.32 \pm 0.1 \mathrm{~b}$ & $0.32 \pm 0.1 \mathrm{~b}$ & $0.36 \pm 0.1 \mathrm{a}$ & $0.3 \pm 0.1 \mathrm{ab}$ \\
\hline${ }^{*} \mathrm{Cd}: 30 \mathrm{mgkg}{ }^{-1 *} \mathrm{~Pb}: 100 \mathrm{mgkg}{ }^{-1}{ }^{* \star} \mathrm{Cr}: 10 \mathrm{mgkg}{ }^{-1}+: \%++: \mathrm{mgkg}^{-1}$ & & & \\
\hline
\end{tabular}

All the macro and micro nutrient elements in the soil of cadmium applied pots were significantly lower (at $5 \%$ significancy level). This shows that EDTA chelator increased the uptake of nutrient elements by the plants.

All the macro and micro nutrient elements, except $\mathrm{Ca}$, in soil increased after the application of EDTA in the pots polluted with lead. This was also obvious in plant results and EDTA application to the soil polluted with Pb increased the uptale of nutrient elements from the soil. Plant available nutrient elements were found to be higher in EDTA applied soils after the experiment. These results were statistically significant at the level of $5 \%$.

The effects of EDTA applications on some macro and micro nutrient elements of soils after the chromium polluted pots differ. $\mathrm{Mg}$ and $\mathrm{P}$ of the macro nutrient elements and Fe, Zn, and $\mathrm{Mn}$ micro nutrient elements were found to be higher after the application of EDTA. The solubilities of the mentioned elements were significanly (at $5 \%$ level) and positively affected.

Soil lead content depends heavily on soil $\mathrm{pH}$, colloid size and cation exchange capacity. Moreover, root surface area, root excretions and transpiration degree affect the absorption and usability of $\mathrm{Pb}$. Plant roots absorb $\mathrm{Pb}$ via $\mathrm{Ca}^{2+}$ channels or in an apoplastic way (Kumar et al. 2019; Pourrutet al. 2011). 
Chromium ( $\mathrm{Cr}$ ) is accepted as one of the most toxic heavy metals and abounds in the eath crust. It enters the food chain via the plant absorption. It is found as chromite $\left(\mathrm{FeCr}_{2} \mathrm{O}_{4}\right)$ or as a complex with other metals in ultramaphic and serpentine rocks and in nature (Oliveira 2012). Moreover, $\mathrm{Cr}$ is released into the ecosystesms as a result of antropogenic activities such as inconscious use of chemical fertilizers, melting of metals, municipality waste waters, and wastes of different industries such as textile, ceramic, leather, steel and galvanic industries (Adhikari et al. 2020; Avudainayagam et al. 2003). Low affinity sulfate carriers mediate the absorption of chromium $\left(\mathrm{Cr}^{+6}\right)$ (Skeffington et al. 1976).

The relationship between $\mathrm{Cr}$ absorption from soil solution to the plant bodies and orgabnic acids in the soil solution was determined, and together with the increased organic acid concentration in soil, the plants were shown to absorb more $\mathrm{Cr}$ from soil solution (Srivastava et al. 1999).

\section{Conclusion And Suggestions}

Health problems related with environmental pollution increase day by day. Uncontrolled polluted agricultural soils and the unability of remediation form the basis of these problems. The studies revealed that heavy metals reached significant levels in soils of our country. This study investigated the potential of phytoremediation method for cleaning up of soils and to carry out a healthy agricultural production. High quality soils will improve public health and life quality through the plants and animals. The usability of Broccoli (Brassicaoleracea var. italica) as a hyperaccumulator plant to remediate cadmium, chromium and lead from the soils contaminated due to industrial activities, intense population and intense traffic was revealed by this study. This plant is especially important for the removal of heavy metal lead. Because this contaminant was accumulated especially in the upper parts of the plant and this plant was showed to be a hyperaccumulator to phytoextract the contaminant. Chromium and cadmium accumulated more in the roots of the plant. For these heavy metals, rhizofiltration can be suggested as a phytoremediation method.

Remediation of heavy metal contaminated agricultural soils is vital for the sustainable productivity of soils. Because, contaminated soils negatively affect the health of the organisms, especially humans. Use of hyperaccumulator plants for the remediation of such soils has become popular recently and heavy metals can therefore be cleaned up successfully from the agricultural soils. This study revealed the potential of broccoli (Brassica oleracea var. italica) to remediate the heavy metals $\mathrm{Cr}$, $\mathrm{Cd}$ and $\mathrm{Pb}$ from the soils. The use of hyperaccumulator plants such as broccoli has been suggested to phytoremediate the ongoing heavy metal pollution in agricultural fields for healty and quality crop production.

\section{Declarations}

\section{Funding}

Not applicable

\section{Ethical Approval}

Not applicable

\section{Consent to Participate}

Not applicable

Consent to Publish

Not applicable 
Sevinç Adiloğlu: 100\%

\section{Funding}

Not applicable

\section{Competing Interests}

The author declares no competing interests.

\section{Availability of data and materials}

Not applicable

\section{References}

1. Adhikari A, Adhikari S, Ghosh S, Azahar I, Shaw AK, Roy D, Hossain Z (2020) Imbalance of redox homeostasis and antioxidant defense status in maize under chromium (VI) stress. Environmental and Experimental Botany, p 169

2. Adiloğlu S (2013) An investigation of some heavy metal pollution along the TEM motorway soils in Tekirdağ. Namık Kemal University, Institute of science, Doctoral thesis

3. Adiloğlu S (2021) Relation of chelated iron (EDDHA-Fe) applications with iron accumulation and some plant nutrient elements in basil (Ocimum Basilicum L.). Pol. J Environ Stud 30(4):3471-3479

4. Adiloğlu S, Göker M (2021) Phytoremediation: elimination of hexavalent chromium heavy metal using corn (Zea Mays L.). Cereal Res Commun 49(1):65-72

5. Adiloğlu A, Adiloğlu S (2003) The investigation of some available trace element contents of acid soils in Turkey. Arch Agron Soil Sci 49(2):179-185

6. Adiloğlu S, Sağlam MT, Adiloğlu A, Süme A (2016) Removal of Nickel (Ni) from agricultural field soils by phytoremediation using canola (Brassica napus L.). Desalination Water Treat 57(6):2383-2388

7. Adiloğlu S (2016) Using phytoremediation with canola to remove cobalt from agricultural soils. Polish Journal of Environmental Studies 25(6):2251-2254

8. Adiloğlu S (2017) Interaction of manganese and some heavy metals in dock (Rumex patientia L.) plant for remediation of contaminated soils. Desalination Water Treat 93:335-338

9. Adiloğlu S (2018) Advances in bioremediation and phytoremediation. Chapter: Heavy Metal Removal With Phytoremediation. In: Naofumi Shiomi (ed), InTech. ISBN 978-953-51-3957-7. pp 200

10. Adiloğlu S (2020) Interaction of some heavy metals with copper content in dock Plant. KSÜ Tarım ve Doğa. Dergisi 23(4):1078-1084

11. Adiloğlu S, Eryilmaz Açıkgöz F, Gürgan M (2021) Use of phytoremediation for pollution removal of hexavalent chromium-contaminated acid agricultural soils. Global Nest 23(3):400-406

12. Adiloğlu S, Gürgan M (2020) Brassica napus: cultivation and uses. Chapter title: Brassica napus: phytoremediation. In: Karoline Møller (Ed), Nova Science Publishers, pp 134. ISBN:978-1-53618-191-3

13. Adiloğlu S, Sağlam MT (2015) Tekirdağ ilinde Karayolu Kıyısındaki Toprakların Organik Madde Miktarları.KSÜ Doğa Bilimleri Dergisi, Special Issue:49-60

14. Adiloğlu S, Pamay S (2021) The future of phytoremediation. Chapter title: Phytoremediation and Hyperacumulative families. In: James C. Flores (Ed) Nova Science Publishers, ISBN:978-1-53619-625-2 pp 305

15. Ali NA, Dewez D, Didur O, Popovic R (2006) Inhibition of photosystem II photochemistry by Cr is caused by the alteration of both D1 protein and oxygen evolving complex. Photosynth Res 89(2):81-87 
16. Asri F, Sönmez S (2006) Ağır metal toksisitesinin bitki metabolizması üzerine etkileri. Derim, Batı Akdeniz Tarımsal Enstitüsü Dergisi 23(2):36-45

17. Avudainayagam S, Megharaj M, Owens G, Kookana RS, Chittleborough D, Naidu R (2003) Chemistry of chromium in soils with emphasis on tannery waste sites. Rev Environ Contam Toxicol 178:53-91

18. Baryla A, Carrier P, Franck F, Coulomb C, Sahut C, Havaux M (2001) Leaf chlorosis in oilseed rape plants (Brassica napus) grown on cadmium-polluted soil: Causes and consequences for photosynthesis and growth. Planta 212(56):696-709

19. Bouyoucos GJ (1955) A recalibration of the hydrometer method for making mechanical analaysis of the soils. Agron $\mathrm{J}$ 4(9):434

20. Chang YC, Zouari M, Gogorcena Y, Lucena JJ, Abadía J (2003) Effects of cadmium and lead on ferric chelate reductase activities in sugar beet roots. Plant Physiol Biochem 41(11-12):999-1005

21. DalCorso G, Farinati S, Maistri S, Furini A (2008) How plants cope with cadmium: Staking all on metabolism and gene expression. J Integr Plant Biol 50(10):1268-1280

22. Daud MK, Ali S, Abbas Z, Zaheer IE, Riaz MA, Malik A, Zhu SJ (2018) Potential of Duckweed (Lemna minor) for the Phytoremediation of Landfill Leachate. Journal of Chemistry https://doi.org/10.1155/2018/3951540. ID 3951540, pp 9

23. Di Cagno R, Guidi L, De Gara L, Soldatini GF (2001) Combined cadmium and ozone treatments affect photosynthesis and ascorbate-dependent defences in sunflower. New Phytol 151(3):627-636

24. Didur O, Dewez D, Popovic R (2013) Alteration of chromium effect on photosystem II activity in Chlamydomonas reinhardtii cultures under different synchronized state of the cell cycle. Environ Sci Pollut Res 20(3):1870-1875

25. Diwan H, Ahmad A, lqbal M (2012) Chromium-induced alterations in photosynthesis and associated attributes in Indian mustard. J Environ Biol 33(2):239-244

26. Dogan M (2019) Effect of cadmium, chromium, and lead on micropropagation and physio-biochemical parameters of Bacopa monnieri (L.) Wettst cultured in vitro. Rendiconti Lincei Scienze Fisiche e Naturali 30(2):351-366

27. Dökmeci AH, Adiloğlu S (2020) The Phytoremediation of chrome from soil using (Cirsium Vulgare) and the health effects of Bioaccumulation. Biosciences Biotechnology Research Asia17(3):535-541

28. EPA (Environmental Protection Agency) (2000) Introduction to Phytoremediation, EPA/600/R-99/107, National Risk Management Research. Laboratory Office of Research and Development U.S. Environmental Protection Agency Cincinnati. Ohio 45268, USA.

29. EPA Method 3052 (1996) Microwave Assisted Acid Digestion of Siliceous and Organically Based Matrices. 1.0. EPA (Vol. 66)

30. Geiken B, Masojídek J, Rizzuto M, Pompili ML, Giardi MT (1998) Incorporation of [35S] methionine in higher plants reveals that stimulation of the D1 reaction centre II protein turnover accompanies tolerance to heavy metal stress. Plant, Cell Environ 21(12):1265-1273

31. Guo TR, Zhang GP, Zhou MX, Wu FB, Chen JX (2007) Influence of Aluminum and Cadmium Stresses on Mineral Nutrition and Root Exudates in Two Barley Cultivars. Pedosphere 17(4):505-512

32. Gupta AK, Verma SK, Khan K, Verma RK (2013) Phytoremediation using aromatic plants: A Sustainable approach for remediation of heavy metals polluted sites. Environ Sci Technol 47:10115-10116

33. Hayat S, Khalique G, Irfan M, Wani AS, Tripathi BN, Ahmad A (2012) Physiological changes induced by chromium stress in plants: An overview. Protoplasma 249(3):599-611

34. Hernández LE, Carpena-Ruiz R, Gárate A (1996) Alterations in the mineral nutrition of pea seedlings exposed to cadmium. J Plant Nutr 19(12):1581-1598

35. Jackson MC (1967) Soil chemical analysis. Prentice Hall of India Private Limited, New Delhi

Page $13 / 16$ 
36. Järup L (2003) Hazards of heavy metal contamination. Br Med Bull 68:167-182

37. Jinadasa N, Collins D, Holford P, Milham PJ, Conroy JP (2016) Reactions to cadmium stress in a cadmium-tolerant variety of cabbage (Brassica oleracea L.): is cadmium tolerance necessarily desirable in food crops? Environ Sci Pollut Res 23(6):5296-5306

38. Jones J, Benton W Jr, Benjamin MA, Harry (1991) Plant Analysis Handbook: A practical sampling, preparation, analysis, and Interpretation guide, 1st edn. Micro Macro Intl, USA

39. Kacar B, İnal A (2010) Bitki Analizleri. Nobel Yayıncılık, Ankara

40. Kacar B (1995) Bitki ve Toprağın Kimyasal Analizleri. III. Toprak Analizleri. A.Ü. Ziraat Fak. Eğit., Araşt. ve Gel. Vakfı Yay. 3, Ankara, No

41. Karaman MR, Adiloğlu A, Brohı R, Güneş A, İnal A, Kaplan M, Katkat V, Korkmaz A, Okur N, Ortaş I, Saltalı K, Taban S, Turan M, Tüfenkçı Ş, Zengin M (2012) Bitki Besleme. Ankara (Turkey). Dumat Ofset

42. Khan MA, Khan S, Khan A, Alam M (2017) Soil contamination with cadmium, consequences and remediation using organic amendments. Sci Total Environ 601-602:1591-1605

43. Kumar V, Singh J, Kumar P (2019) Contaminants in Agriculture and Environment: Health Risks and Remediation. Agriculture and Ennvironmental Science Academy. Agro Environ Media Haridwar, India, Editor

44. Küpper H, Parameswaran A, Leitenmaier B, Trtílek M, Šetlík I (2007) Cadmium-induced inhibition of photosynthesis and long-term acclimation to cadmium stress in the hyperaccumulator Thlaspi caerulescens. New Phytol 175(4):655674

45. Lindsay WL, Norvell WA (1978) Development of a DTPA soil test for zinc, iron, manganase and copper. Soil Sci Soc Am J 42:421-428

46. Liu D, Li TQ, Jin XF, Yang XE, Islam E, Mahmood Q (2008) Lead induced changes in the growth and antioxidant metabolism of the lead accumulating and non-accumulating ecotypes of Sedum alfredii. J Integr Plant Biol 50(2):129-140

47. Mahmood Q, Asif M, Shaheen S, Hayat MT, Ali S (2019) Cadmium Contamination in Water and Soil. Cadmium Toxicity and Tolerance in Plants. Elsevier Inc.. Faisalabad, Pakistan, Editor

48. Mathur S, Kalaji HM, Jajoo A (2016) Investigation of deleterious effects of chromium phytotoxicity and photosynthesis in wheat plant. Photosynthetica 54(2):185-192

49. Maxwell K, Johnson GN (2000) Chlorophyll fluorescence-A practical guide. J Exp Bot 51(345):659-668

50. Metwally A, Safronova VI, Belimov AA, Dietz KJ (2005) Genotypic variation of the response to cadmium toxicity in Pisum sativum L. J Exp Bot 56(409):167-178

51. Mishra S, Srivastava S, Tripathi RD, Kumar R, Seth CS, Gupta DK (2006) Lead detoxification by coontail (Ceratophyllum demersum L.) involves induction of phytochelatins and antioxidant system in response to its accumulation. Chemosphere 65(6):1027-1039

52. Moussa HR, El-Gamal SM (2010) Effect of salicylic acid pretreatment on cadmium toxicity in wheat. Biol Plant 54(2):315-320

53. Oliveira H (2012) Chromium as an Environmental Pollutant: Insights on Induced Plant Toxicity,Journal of Botany1-8

54. Olsen SR, Sommers LE (1982) Methods of soil analysis. Part II. Chemical and microbiological properties. Editors: Page, A.L., R.H. Miller, D.R. Keeney. Agronomy. No: 9 Madison, Wisconsin, USA

55. Ow DW (1996) Heavy Metal Tolerance Genes: Prospective Tools for Bioremediation Resources. Conservation Recycling 18:135-149

56. Pan L, Ma J, Wang X, liang, Hou H (2016) Heavy metals in soils from a typical county in Shanxi Province, China: Levels, sources and spatial distribution. Chemosphere 148:248-254

57. Panda SK, Choudhury S (2005) Chromium stress in plants. Braz J Plant Physiol 17(1):95-102

Page $14 / 16$ 
58. Pandey V, Dikshit V, Shyam R (2013) Hexavalent Chromium Induced Inhibition of Photosynthetic Electron Transport in Isolated Spinach Chloroplasts. Photosynthesis. Editor: Zvy Dubinskyhttps. IntechOpen, Israel

59. Popova L, Maslenkova L, Yordanova R, Krantev A, Szalai G, Janda T (2008) Salicylic Acid Protects Photosynthesis Against Cadmium Toxicity in Pea Plants, Gen. Appl Plant Physiology 34(3-4):133-148

60. Pourrut B, Shahid M, Dumat C, Winterton P, Pinelli E (2011) Lead Uptake, Toxicity, and Detoxification in Plants. Rev Environ Contam Toxicol 232:61-88

61. Pradhan SK, Kumar U, Singh NR, Thatoi H (2019) Functional diversity and metabolic profile of microbial community of mine soils with different levels of chromium contamination,International Journal of Environmental Health Research113

62. Rafiq MT, Aziz R, Yang X, Xiao W, Rafiq MK, Ali B, Li T (2014) Cadmium phytoavailability to rice (Oryza sativa L.) grown in representative Chinese soils. A model to improve soil environmental quality guidelines for food safety. Ecotoxicol Environ Saf 103(1):101-107

63. Rizwan M, Ali S, Adrees M, Ibrahim M, Tsang DCW, Zia-ur-Rehman M, Ok YS (2017) A critical review on effects, tolerance mechanisms and management of cadmium in vegetables. Chemosphere 182:90-105

64. Romanowska E, Wróblewska B, Drozak A, Siedlecka M (2006) High light intensity protects photosynthetic apparatus of pea plants against exposure to lead. Plant Physiol Biochem 44(5-6):387-394

65. Sadowsky MJ (1999) Phytoremediation: Past Promises and Future Practises, Microbial Biosystems: New Frontiers. Atlantic Canada Society for Microbial Ecology, Halifax, Canada

66. Sağlam MT (2012) Toprak ve Suyun Kimyasal Analiz Yöntemleri. Namık Kemal Üniversitesi. 2, Yayın No, pp Tekirda-

67. Salido AL, Hasty KL, Lim JM, Butcher DJ (2003) Phytoremediation of Arsenic and Lead in Contamined Soil Using Chinese Brake Ferns (Pteris vittata L.) and Indian Mustard (Brassica juncea L.). International J of Phytoremediation 5(2):89-103

68. Sethuraman P, Balasubramanian N (2010) Removal of $\mathrm{Cr}(\mathrm{VI})$ from aqueous solution using Bacillus subtilis, Pseudomonas aeruginosa and Enterobacter cloacae. International Journal of Engineering Science and Technology 2(6):1811-1825

69. Sethy SK, Ghosh S (2013) Effect of heavy metals on germination of seeds. Journal of Natural Science, Biology and Medicine 4(2):272-275

70. Shanmugaraj BM, Malla A, Ramalingam S (2019) Cadmium Stress and Toxicity in Plants: An Overview. Cadmium Toxicity and Tolerance in Plants from Physiology to Remediation. Mirza Hasanuzzaman, Majeti Narasimha Vara Prasad ve Masayuki Fujita. India. Elsevier, Editor

71. Sharma P, Dubey RS (2005) Lead toxicity in plants. Braz J Plant Physiol 17:35-52

72. Sigfridsson KG, V, Bernát G, Mamedov F, Styring S (2004) Molecular interference of Cd 2+ with Photosystem II. Biochimica et Biophysica Acta-Bioenergetics 1659(1):19-31

73. Singh HP, Mahajan P, Kaur S, Batish DR, Kohli RK (2013) Chromium toxicity and tolerance in plants. Environ Chem Lett 11(3):229-254

74. Singh R, Tripathi RD, Dwivedi S, Kumar A, Trivedi PK, Chakrabarty D (2010) Lead bioaccumulation potential of an aquatic macrophyte Najas indica are related to antioxidant system. Bioresour Technol 101(9):3025-3032

75. Srivastava S, Prakash S, Srivastava MM (1999) Chromium Mobilization and Plant Availability the Impact of Organic Complexing Ligands. Plant Soil 212:203-208

76. Susplugas S, Srivastava A, Strasser RJ (2000) Changes in the photosynthetic activities during several stages of vegetative growth of Spirodela polyrhiza: Effect of chromate. J Plant Physiol 157(5):503-512

77. Tang X, Li Q, Wu M, Lin L, Scholz M (2016) Review of remediation practices regarding cadmium-enriched farmland soil with particular reference to China. J Environ Manage 181:646-662

Page 15/16 
78. Todorenko D, Timofeev N, Kovalenko I, Kukarskikh G, Matorin D, Antal T (2020) "Chromium effects on photosynthetic electron transport in pea (Pisum sativum L.)". Planta 251(1):1-13

79. Vajpayee P, Tripathi RD, Rai UN, Ali MB, Singh SN (2000) Chromium (VI) accumulation reduces chlorophyll biosynthesis, nitrate reductase activity and protein content in Nymphaea alba L. Chemosphere 41(7):1075-1082

80. Van Assche F, Clijsters H (1983) Multiple Effects of Heavy Metal Toxicity on Photosynthesis. In: Marcelle R, Clijsters H, van Poucke M (eds) Effects of Stress on Photosynthesis. Dordrecht: Springer, Netherlands, Editors

81. Wahid A, Ghani A, Javed F (2008) Effect of cadmium on photosynthesis, nutrition and growth of mungbean. Agron Sustain Dev 28(2):273-280

82. Wallace A, Soufi SM, Cha JW, Romney EM (1976) Some effects of chromium toxicity on bush bean plants grown in soil. Plant Soil 44:471-473

83. Yang T, Poovaiah BW (2003) Calcium/calmodulin-mediated signal network in plants. Trends Plant Sci 8(10):505-512

\section{Figures}

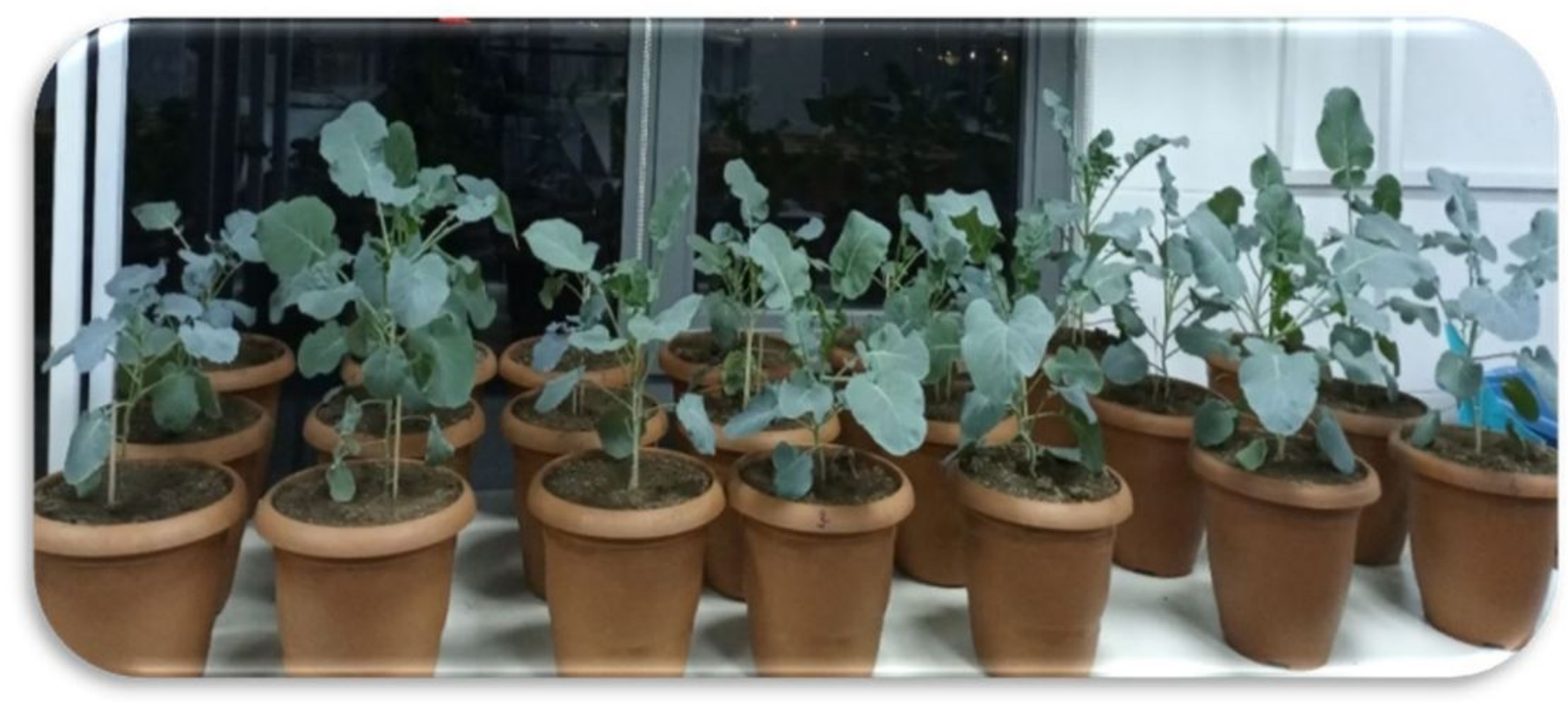

Figure 1

A photo from experimental process (original). 